\title{
EFFECT OF DIETARY CHROMIUM, SELENIUM AND VITAMIN C SUPPLEMENTATION TO THE DIET ON REPRODUCTIVE PERFORMANCE AND EGG QUALITY OF LAYING HENS DOKKI-4 UNDER EGYPTIAN SUMMER CONDITION
}

\author{
Kh . M. Attia; F.A. Tawfik; M.S. Mady and M.H. Assar \\ Animal Production Research Institute, Agricultural Research Center, Ministry of Agriculture, Dokki, \\ Egypt.
}

SUMMARY

$\mathrm{T}$ The study was performed to evaluate the effect of organic chromium $(\mathrm{Cr})$, organic selenium $(\mathrm{Se})$ or vitamin $\mathrm{C}$ (vit. C) alone or in combination on reproductive performance, and egg quality of Dokki4 laying hens under hot summer conditions of Egypt. A total number of 240 hens plus 48 cocks from Dokki-4 strain at 30 weeks of age were randomly selected and distributed into eight groups with 3 replicates ( 10 hens +1 cock) each. The remaining 24 cocks were also divided into 8 groups of 3 cocks each and housed separately for semen evaluation experiment. Treatments groups were fed a basal diet (control group) or the basal diet supplemented with either $400 \mu \mathrm{g} \mathrm{Cr} / \mathrm{kg} \operatorname{diet}(\mathrm{Cr}$ group), $250 \mathrm{mg}$ of L-ascorpic acid $/ \mathrm{kg}$ diet (vit. C. group), $0.2 \mathrm{mg} \mathrm{Se} / \mathrm{kg}$ diet (Se group), $400 \mu \mathrm{g} \mathrm{Cr}$ plus $250 \mathrm{mg}$ of L-ascorpic acid/ $\mathrm{kg} \mathrm{diet} \mathrm{(Cr}+\mathrm{vit}$. $\mathrm{C}$ group), $400 \mu \mathrm{g}$ Cr plus $0.2 \mathrm{mg} \mathrm{Se} / \mathrm{kg} \operatorname{diet}$ ( $\mathrm{Cr}+\mathrm{Se}$ group), $2 \mathrm{mg}$ Se plus $250 \mathrm{mg} \mathrm{L-ascorbic} \mathrm{acid} / \mathrm{kg} \mathrm{diet} \mathrm{(}$ $\mathrm{Se}+$ vit. C. group) and $400 \mu \mathrm{Cr}$ plus $0.2 \mathrm{mg}$ Se plus $250 \mathrm{mg}$ ascorbic acid $/ \mathrm{Kg} \operatorname{diet}(\mathrm{Cr}+\mathrm{Se}+\mathrm{vit} . \mathrm{C}$ group). All groups were put under observation for 12 weeks. Results obtained can be summarized as follows: Supplementation of $\mathrm{Cr}$, Se or vitamin $\mathrm{C}$ alone or in combinations significantly increased $(\mathrm{P}<0.05)$ shell thickness, haugh units, albumin and shell to egg weight, sperm motility, ejaculate volume, sperm concentration, total sperm output, total motile sperm, live spermatozoa, semen quality factor and significantly decreased $(\mathrm{P}<0.05)$ dead spermatozoa and seminal malondialdehyde (MDA) as compared with control group. The best result was obtained for layers fed diet containing the combinations of the three supplements (Cr, Se or vitamin C) as compared to other groups.

In conclusion, combinations of $\mathrm{Cr}$, $\mathrm{Se}$ and vitamin $\mathrm{C}$ improved the most reproductive traits and egg quality of Dokki-4 strain under Egyptian hot summer.

Keywords: Laying hens, chromium, selenium and vit. C supplementation, reproductive performance and egg quality.

\section{INTRODUCTION}

Nowadays in Egypt there is necessity of increasing animal production to fulfill the insisting demand of animal protein. It is noticed that the price of animal protein is getting higher during the last few years. So, the increase in animal protein production may come from the poultry. Poultry feeding and management could be considered very reasonable in cost if compared with the other animals. One of the problems challenging in poultry industry is the high ambient temperature, which persists in Egypt for about 5 months per year (May to September), as it is can compromise the ability of birds to maintain homeostasis (Kadim et al., 2008). It depresses body weight, egg production, weight, quality and hatchability and increase mortality (Pavlik et al., 2009). Heat stress begins when the ambient temperature becomes higher than $27^{\circ} \mathrm{C}$ and is readily apparent above $30^{\circ} \mathrm{C}$ (Bollengier-lee et al., 1998). Heat stress leads to generation of free radicals, such as $\mathrm{O}$ - and $\mathrm{HO}$. These free radicals can damage cell membranes by inducing lipid peroxidation of polyunsaturated fatty acids in the cell membrane (NRC, 1994). Because radical reactions are exergonic, they contribute with failure of the thermoregulation process to the increase of body temperature observed during heat stress. As a result, dietary supplementation of these two antioxidant compounds would attenuate the deleterious heat-induced- oxidative stress. Heat stress increases the need for antioxidants, because birds can not synthesize enough ascorbate during hot conditions (Cheng et al., 1990), and dietary supplementation with high dosages of antioxidants, such as vitamin $\mathrm{C}$ and $\mathrm{E}$, have been conducted. 
Various techniques are being practiced by the farmers to minimize the heat stress, such as adding antioxidant, vitamins or minerals such as selenium, vitamins $\mathrm{C}, \mathrm{E}$ and folic acid, zinc and chromium (Sahin et al., 2002).

On the other hand, vitamin $\mathrm{C}$ is an indispensable micronutrient required to maintain the physiological processes of poultry (McDowell, 1989). Kutlu and Forbes (1993) reported that ascorbic acid reduces the synthesis of corticosteroid hormones in birds. Similarly, Sahin et al. (2002) reported that lower concentrations of adrenocorticotropic hormone (ACTH) in quail reared at $32^{\circ} \mathrm{C}$ and fed a diet supplemented with vitamin $\mathrm{C}$ than in the heat-stressed controls. By decreasing synthesis and secretion of corticosteroids, vitamin C alleviates the negative effects of stress (McDowell, 1989). Desoky (2008) found that dietary supplementation of vitamin $\mathrm{C}$ showed high ability of alleviating the negative effect of heat stress and improved egg production and egg quality. Moreover, vitamin $\mathrm{C}$ itself plays important roles in cellular anti-oxidant defenses, not only by reacting with all oxygen species through formation of dehydroascorbyl, a particular inert radical, but also by transferring radical equivalents from lipid phases to the aqueous compartment. In complement, ascorbate participates in the regeneration of reduced glutatione from the oxidized form in the cytoplasm and allows tocopherol regeneration through a nonenzymatic reaction (Ciftci et al., 2005).

Organic $\mathrm{Cr}$ compounds can be absorbed about 20-30 times more efficiently than inorganic forms (Piva et al., 2003). Uyanik et al., (2002) have shown that $\mathrm{Cr}$ absorption is higher when it is associated with a specific organic molecule. A number of organic $\mathrm{Cr}$ preparations are commercially available to protect animals from stress associated with environmental and management conditions of intensive livestock farming. Chromium-methionine (Cr-Met) chelate is a newly developed organic $\mathrm{Cr}$ which is able to directly cross the intestinal cell membrane and be metabolized without any prior digestion since it was chelated with amino acid. Thus, bioavailability of $\mathrm{Cr}$-Met chelate is proposed to be higher than those of other organic $\mathrm{Cr}$.

On the other hand, selenium ( $\mathrm{Se}$ ) has been recognized as an essential nutrient required for laying hens for normal growth, maintenance of health and physiological functions. The role of Se in biological systems has been associated with its antioxidant activity (Schwary and Foltz, 1957), while its physiological importance was recognized when it is found to be an essential structural of the glutathione peroxidase enzymes (Rotruck et al., 1973) that destroy free radicals produced during normal metabolic activity (Wakebe, 1998 ). The use of seleno-yeast (SY) in laying hens is very effective for increasing the Se content of egg (Utterback et al., 2005). However, Se can affect egg quality where, it can ameliorate some of the adverse effects of strong Haugh unit value of eggs (Pappas et al., 2005). Also, it may affect metabolism and production because it is essential for the synthesis of active thyroid hormones, while, no differences in egg production, egg weight, feed intake or mortality by using organic SY which is very effective for increasing the Se content of eggs (Utterback et al., 2005).Therefore, adding Se to laying diets improves their health, productivity and can also be a natural way to produce functional food respectivity the production of egg enriched with Se (Yaroshenko et al., 2003 and Sara et al., 2008), which represents a commercially valuable use for the future.

This study was carried out to establish the dietary supplementation of chromium, selenium and vitamin $\mathrm{C}$ either alone or in combinations on reproductive traits, egg quality, and economic efficiency of Dokki-4 strain, under hot summer conditions.

\section{MATERIALS AND METHODS}

The experimental work of this study was carried out at Sakha Poultry Research Station, Animal Production Research Institute, Egypt. The chemical analyses were carried out at Laboratories of the Animal Production Research Institute, Ministry of Agriculture, Egypt during summer season (from June to August, 2014). The average minimum and maximum ambient temperatures ranged between 21.75 and $40.65^{\circ} \mathrm{C}$, relative humidity from 31.8 to $80.7 \%$ and temperature-humidity index (THI) from 36.0 to $51.39 \%$ under under Kafr El-Sheikh Governorate, Egypt (Central Laboratory for Agricultural Climate) as show in Table 2 which was a burden on the chickens According to Marai et al. (2002) there is severe heat stress when THI is higher than 28.9.

The THI was calculated according to the formula by Marai et al. (2001) as follows:

$\mathrm{THI}=\mathrm{db}^{\circ} \mathrm{c}-\left[(0.31-0.31 \mathrm{RH}) \times\left(\mathrm{db}^{\circ} \mathrm{c}-14.4\right)\right]$

Where: $\mathrm{db}^{\circ} \mathrm{c}$ is dry bulb temperature in Celsius degrees, and RH is the relative humidity as a percentage.

A total number of 264 (240 laying hens +48 cocks) chickens (Egyptian strain, Dokki-4), 30 weeks old were individually leg-banded, weighed and randomly distributed into 8 groups of 3 replicates (10 laying hens +1 cock / replicate). The remaining 24 cocks were also divided into 8 groups of 3 cocks each and 
housed separately for semen evaluation experiment. The birds were housed in floor pens in an open house and photoperiod of 17 hours daily. Birds were kept under the same managerial and hygienic conditions. Birds were healthy and examined against diseases and treated with antibiotics and vaccines.

A corn-soybean meal basal experimental layer diet ( 16\% and $2750 \mathrm{kcal} \mathrm{ME} / \mathrm{kg}$ diet) was formulated to cover all recommended nutrient requirements according to the Egyptian Feed Composition Table (2001) as shown in Table (1). Treatments groups were fed a basal diet (control group) or the basal diet supplemented with either $400 \mu \mathrm{g} \mathrm{Cr} / \mathrm{kg}$ diet (Cr group), $250 \mathrm{mg}$ of L-ascorbic acid / $\mathrm{kg}$ diet (Vit. C group), $0.2 \mathrm{mg}$ of Se / $\mathrm{kg}$ diet (Se group), $400 \mu \mathrm{g}$ Cr plus, $250 \mathrm{mg}$ of L-ascorbic acid / $\mathrm{kg}$ diet $(\mathrm{Cr}+\mathrm{Vit}$. C group), $400 \mu \mathrm{g}$ Cr plus $0.2 \mathrm{Se} / \mathrm{kg} \operatorname{diet}(\mathrm{Cr}+\mathrm{Se}$ group), $0.2 \mathrm{mg}$ Se plus $250 \mathrm{mg}$ ascorbic acid $/ \mathrm{kg} \operatorname{diet}(\mathrm{Se}$ + Vit $\mathrm{C}$ group) and $400 \mu \mathrm{g} \mathrm{Cr}$ plus $0.2 \mathrm{Se}+250 \mathrm{mg}$ ascorbic acid / $\mathrm{kg}$ diet $(\mathrm{Cr}+\mathrm{Se}+\mathrm{Vit}$. C group), respectively. Chromium-methionine $\left\{\mathrm{Cr}\left(\mathrm{C}_{5} \mathrm{H}_{10} \mathrm{NO}_{2} \mathrm{~S}\right)_{3}\right\}$, alight violet-red crystalline powder containing $1 \% \mathrm{Cr}$, was the source of the supplemental Cr. Vitamin C (ROVIMX® x STAY-C® 35) was provided by a commercial company (Roche, Levent-Istanbul, Turkey). Organic selenium was SelPlex ${ }^{\mathrm{TM}}$ in the form of selenium yeast (Alltech Inc.) contained $1000 \mathrm{ppm}$ organic selenium and produced by the fermentation of yeast (Saccharomyces cerevisiae) in a high organic selenium medium.

\section{Egg quality measurements:}

Five representative eggs from each treatment were collected monthly throughout the experimental period in order to determine egg and shell quality.

Parameters measured for egg quality were egg shape index (\%) was calculated according to Romanoff and Romanoff (1949) as an egg diameter divided by an egg length. Estimated as the ratio of the egg maximum width to its length, shell thickness was measured in mm using a micrometer. Yolk index was calculated according to Funk et al. (1958), as yolk height divided by yolk diameter. Haugh unit was calculated according to Eisen et al. (1962) using the calculation chart for rapid conversion of egg weight and albumen height. Arc-sine transformations were done for percentage of egg shape index and yolk, albumin and shell percentages before stimulation of the data. Haugh unit score was calculated for each individual egg according to Haugh (1937).

Egg shells were ground prior to ashing $\left(600^{\circ} \mathrm{C}\right.$ for $\left.6 \mathrm{~h}\right)$. Calcium and phosphorus were determined according to the methods of the Association of Official Analytical Chemists (2005).

Effect of storage time on malondialdehyde concentration:

Malondialdehyde, yolk $\mathrm{pH}$ was studied at $0,5,10$ and 15 days after storage of three eggs from each treatment at $\left(20\right.$ to $\left.23^{\circ} \mathrm{C}\right)$ and $60 \% \mathrm{RH}$. Malondialdehyde was measured according to Marshall et al. (1994). The values of malondialdehyde were expressed in terms ( $\mathrm{mg} / \mathrm{kg}$ egg yolk) as reported by Wang and Pan (2003). Yolk pH during storage was measured as reported by (Kirunda and McKee, 2000). The previous analyses were done at Lab. Of Food Science, Faculty of Agriculture, Cairo Univ., Giza. Five representative eggs from each treatment were collected monthly throughout the experimental period and yolk samples were separated from the broken eggs, calculated and extracted according to Folch et al., (1957). Total lipids, cholesterol, LDL, HDL and triglycerides were colorimetrically determined in egg yolk.

Monthly semen sample was collected from cocks by the massage method from all cocks. Semen ejaculate volume was measured by tuberculin syringe graduated to nearest $0.01 \mathrm{ml}$ according to Allen and Champion (1955). Sperm concentration was determined by using Thomes-Zeis haemocytometer (Kalamah et al., 2000). Total sperm output was calculated by multiplying ejaculate volume and spermatozoa concentration. Percentage of live and abnormal sperms were determined after staining with eosine and nigrosine (Blom, 1950), then calculated as a percentage out of randomly chosen 100 sperm counted. Percentage of motile sperm was estimated by visual examination under low-power magnification (10x) using a phase-contrast microscope according to Melrose and Laing (1970). Total number of motile sperm (TMS) calculated by multiplying percentage of motile sperm and total sperm output. Semen quality factor $(\mathrm{SQF})$, calculated according to the following pattern was used: $\mathrm{SQF}=$ (sperm concentration $\mathrm{x}$ ejaculate volume $\mathrm{x}$ live spermatozoa) / 100, Hydrogen ion concentration $(\mathrm{pH})$ of semen was determined immediately after collection using $\mathrm{pH}$ paper. Seminal plasma was obtained by centrifugation of semen samples at $3500 \mathrm{rpm}$ for $20 \mathrm{~min}$ at $4^{\circ} \mathrm{C}$, and was stored at $-20^{\circ} \mathrm{C}$ until later analysis. Malondialdehyde (MDA) in seminal plasma was measured in the form of thiobarbituric acid reactive substance (TBARS) as described by Richard et al. (1992).

Eggs of each group were daily collected at $5.00 \mathrm{pm}$ during the last four days of each month, stored in egg room storage at $16-18{ }^{\circ} \mathrm{C}$ and incubated in an automatic electrical incubator at $99-100{ }^{\circ} \mathrm{F}$ and $60-70 \%$ relative humidity with turning at 2-hours intervals. After $14^{\text {th }}$ day of incubation, eggs were transferred to the hatcher (turning was stopped, $96-97^{\circ} \mathrm{F}$ and $80-90 \%$ relative humidity). At hatching time, infertile eggs were examined to determine fertility \% (fertile eggs/ total eggs x 100) and hatchability \% was calculated as hatched chicks/ total eggs $\mathrm{x} 100$. 
Egyptian J. Nutrition and Feeds (2015)

\section{Statistical analysis:}

Data were analyzed using the GLM procedure of SAS® (SAS, 2003) using one-way ANOVA according to the following model:

$\mathrm{Xij}=\mu+\mathrm{Ti}+\mathrm{eij}$

Where: $\mathrm{Xij}=$ any observation.

$\mu=$ Overall mean,

$\mathrm{Ti}=$ Treatments $(\mathrm{i}=1,2 \ldots$ and 8$)$,

eij $=$ Experimental error.

Before analysis, all percentages were subject to logarithmic transformation $(\log 10 \mathrm{x}+1)$ to normalize data distribution. Mean difference at $\mathrm{P} \leq 0.05$ was tested using Duncan's multiple range test (Duncan, 1955).

\section{RESULTS AND DISCUSSION}

\section{Egg quality:}

Egg quality and egg components of Dokki-4 layers as affected by either dietary supplementation of chromium, selenium, vitamin $\mathrm{C}$, or their mixtures during hot summer condition are presented in Table (3). Supplementation of $\mathrm{Cr}$, vitamin $\mathrm{C}$ or Se, singly or in combinations were significantly increased $(\mathrm{P}<0.05)$ the shell thickness, Haugh units, yolk index, shell to egg weight, albumen weight \% calcium and phosphorus levels in shell compared to the control group. It is worth noting that, egg shape index, was not significantly affected by dietary supplementation of $\mathrm{Cr}$, vitamin $\mathrm{C}$ and Se alone or with any combinations. These results agreed with those of Pavlik et al. (2009) who found that exposure of hens to high ambient temperatures resulted in a significant decrease in egg quality traits (shell weight, shell thickness, and specific gravity). These finding could be due to the reduction in feed consumption (data not published). The adverse effect of high environmental temperature on egg shell quality has been well documented (Mahmoud et al., 1996). The decrease in shell quality in the current study may be partially due to a reduction in plasma calcium. It has been reported that plasma calcium level was significantly decreased in laying hens (Mahmoud et al., 1996) when the birds were exposed to high temperatures. Also, the reduction in shell thickness may result from the insufficient intake of nutrients including minerals such as $\mathrm{Ca}$ due to reduced feed intake or insufficient $\mathrm{HCO}_{3}$ level to form $\mathrm{CaCO}_{3}$ due to excess expiration of $\mathrm{CO}_{2}$ or both. The reduction in egg weight (Bollengier-Lee et al., 1998) and shell thickness (Yardibi and Türkay, 2008) reflects the detrimental effects of heat stress on egg shell quality.

These findings agreed with those reported by Essa and Madian (2009) and El-Gendi et al. (1999) who found that eggs were characterized significantly higher $(\mathrm{P} \leq 0.05)$ absolute and relative weights of shell and yolk by vitamin C supplementation. Also, Metwaly (2005) found that hens fed diet with vitamin C had a good quality of yolk, shell weight and shell thickness when compared to the control.

As well, Cheng et al. (1990) reported that shell weight per unit surface area showed a small increase with supplementary ascorbic acid (0,100, and $200 \mathrm{ppm})$ and values (in Haugh units) were increased by ascorbic-acid at a level of $200 \mathrm{mg} / \mathrm{kg}$ with low relative humidity. Desoky (2008) found that dietary supplementation of vitamin C (200 mg vitamin C/ $\mathrm{kg}$ diet) or vitamin E (150 mg vitamin E/ $\mathrm{kg}$ diet) alone or in combination showed high ability of alleviating the negative effect of heat stress and improved egg quality.

Similarly to the results of the present study, El-Boushy et al. (1998) reported that dietary vitamin C supplementation increased egg production and egg shell strength in stressed laying hens. It has been reported that ascorbic acid plays a role in bone maturation by improving hydroxyproline production which is required for collagen formation. Accordingly, in birds, it was postulated that ascorbic acid stimulates 1,25-dihydroxycholecalciferol and together these compounds increase calcium mobilization from bones, suggesting that vitamin $\mathrm{C}$ has an important role in egg shell formation (Sahin and Sahin, 2001). In the present study, vitamin $C$ supplementation significantly increased egg shell thickness and egg shell weight. Chee et al. (2005) reported that vitamin C (200 mg/ kg) supplemented to the diet of broiler breeder hens could prevent drops in egg shell quality under highly stressful environmental temperatures. This may be due to an increased calcium mobilization from bones (Sahin and Sahin, 2001).

Concerning Selenium, egg quality traits were significantly effected $(\mathrm{P}<0.05)$ by using diets containing SY. These results are in agreement with Renema (2006) and Sara et al. (2008), they reported that the administration of organic Se in laying hen diets increased shell-thickness consequently improved egg shell quality. Similar reports by Spring (2006) and Hanafy et al. (2009). However, SY addition, reduced deterioration of the albumen quality which results in slower carbon dioxideloss and thus maintains 
albumen quality after the egg is laid (Wakebe, 1998). Experimental results obtained are in harmony with those reported by Spring (2006) who indicated that organic Se supplementation in broiler and breeder layers improved egg quality and antioxidative properties.

Se supplementation was stated to influence the oestradiol dependent mechanisms by exerting a direct effect on oestradiol or an indirect effect through maintaining more normal function of cellular processes regulating oestradiol and restoration of estrogen secretion (Bolleengier- Lee et al., 1998). Oestradiol has an effect on circulating calcium through its control synthesis of 1,25 dihydroxy cholecalciferol and the active cholecalciferol metabolite that regulates calcium absorption (Taylor and Drake, 1984). Circulating calcium and estrogen concentration are highly correlated in laying hens (Tojo and Huston, 1980).

Concerning feeding $\mathrm{Cr}$-supplemented diets significantly increased shell thickness, albumin weight, yolk index and yolk weight compared to control diet. Similar results were obtained in laying Japanese quail (Sahin et al. 2001, 2002, Yeşilbağ and Eren, 2009 and Abdel-Mageed and Hanan, 2012) and hens (Lien et al. 1999; Uyanık et al., 2002 and Yıldız et al., 2004). Hossain (1998) suggested that the possible mechanisms by which $\mathrm{Cr}$ could work to maintain egg quality are : (1) as a structural component of egg albumen or in the cross linking of proteins, (2) $\mathrm{Cr}$ is necessary for the synthesis of ovomucin which is responsible for gel structure of albumen, and (3) facilitate transfer of cations ( possibly magnesium) into the albumen of egg during the plumping process in the uterus., In Lohman White Laying hens chromium yeast supplementation increased albumen and yolk index (Eseceli et al., 2010). Uyanik et al. (2002) indicated that supplementation of $20 \mathrm{ppm} \mathrm{Cr}$ from chromium chloride supplementation to the diet of laying hens increased albumen and egg yolk index values.

Also, the beneficial effect of organic $\mathrm{Cr}$ on external egg shell traits may be account for the indirect action of $\mathrm{Cr}$ in empowering the ascorbic acid transportation (Seaborn et al., 1994), which has an important role in egg shell formation. Moreover increasing egg shell thickness may due to $\mathrm{Cr}$ stimulates and regulates the action of insulin (Anderson, 1994 and Mowat, 1994); thus increasing the effectiveness of insulin.

\section{Egg yolk constituents:}

Dietary supplementation of chromium, selenium, vitamin $\mathrm{C}$, or their mixtures during hot summer condition decreased $(\mathrm{p} \leq 0.05)$ egg yolk content of total cholesterol, L.D.L., total lipids and triglycerides as compared with the control (Table 4). The results of egg yolk constituents were supported by Ali et al. (2007) who found that addition of thyme and anise as natural antioxidants, in layer diets (Inshas and Dokki-4) decreased LDL, total cholesterol, triglyceride and total lipids in yolk extract. Radwan et al. (2008) found that addition of natural antioxidants, in layer diets (El-Slam strain) significantly decreased yolk lipid in comparison to the control group.

\section{Egg quality during storage:}

Table (5) represent the effect of storage time on egg content $\mathrm{pH}$ and its and malonaldehyde content as response to different treatments.

Egg content $\mathrm{pH}$ in general increased with increasing storage time (Table 5). Addition of chromium, selenium, vitamin $\mathrm{C}$, or their mixtures kept the $\mathrm{pH}$ of egg content lower than that of the control. Egg yolk malonaldehyde increased with increasing storage time (Table 5). Addition of chromium, selenium, vitamin $\mathrm{C}$, or their mixtures resulted in less $(\mathrm{p} \leq 0.05)$ malonaldehyde than that of the control.

In this regard Radwan et al. (2008) found that addition of natural antioxidants in layer diets during laying period significantly decreased malonaldehyde formation in egg yolk and had a positive effect on oxidative stability of shell eggs storage at room temperature $\left(16^{\circ} \mathrm{C} \pm 2\right)$. Samli et al. (2005) supported the effect of egg storage time on $\mathrm{pH}$ of albumen and yolk, where it increased in stored eggs compared with the fresh eggs. The authors observed rapidly increased $\mathrm{pH}$ in albumen with $2 \mathrm{~d}$ of storage time and extended from 7.47 to 9.2 at $29^{\circ} \mathrm{C}$ during $5 \mathrm{~d}$ of storage. They indicated that the increase in $\mathrm{pH}$ observed in yolk was not as large as in albumen and it differed from 5.75 to 6.08 during $10 \mathrm{~d}$ of storage at $29^{\circ} \mathrm{C}$. They explained that most of these changes in egg quality were attributed to water loss by evaporation through the pores in the shell and the escape of carbon dioxide from albumen.

\section{Semen physical characteristics:}

Sperm motility, dead spermatozoa, sperm cell concentration and seminal MDA of Dokki-4 cockerels as affected by dietary supplementation of either $\mathrm{Cr}$, vitamin $\mathrm{C}$, Se or their mixtures during hot summer condition are presented in Table (6). Supplementation of $\mathrm{Cr}$, vitamin $\mathrm{C}$ or Se singly or in combinations were significantly $(\mathrm{P}<0.05)$ increased sperm motility and decreased dead spermatozoa and seminal MDA compared with the control group. While, supplementation of $\mathrm{Cr}$, vitamin $\mathrm{C}$ and $\mathrm{Se}$ in combinations were significantly increased $(\mathrm{P}<0.05)$ sperm cell concentration as compared with control group. These results are in agreement with Hood (1999) who reported that heat exposure caused an increase in the 
percentage of dead sperm (29.1\%) and a decrease in the sperm quality index (SQI) (10.2\%). Whoever, Monsi and Onitchi (1991) supplemented the feed of heat-stressed broiler breeders with 0, 125, 250 or 500 ppm of ascorbic acid and who found that semen volume, total sperm, and motile sperm per ejaculate were significantly increased due to the addition of ascorbic acid. Noll (1997) reported that improved sperm cell concentrations in males and more eggs per hen when turkey breeder diets were supplemented with 200 $\mathrm{mg}$ per $\mathrm{kg}$ of vitamin $\mathrm{C}$. This improved reproductive performance was noted in spite of environmental temperature fluctuations.

Furthermore, these results are in agreement with that reported by Simon (2004) who showed that when broiler breeders were fed diets supplemented with selenium improve sperm morphology and activity. Also, Surai et al. (1998) indicated that the need for defense against oxidative damage is clear in the male, where antioxidant enzymes play a key role in maintaining the sperm cells. Sperm cells contain large amounts of polyunsaturated fatty acids, which allow them to maintain flexibility relating to motility (Surai, 2002). However, this means they are also a target for lipid peroxidation. Cellular integrity is maintained by GSH-Px and other selenoenzymes which protect the cell membranes from oxidative damage (Flohe and Zimmermann, 1970). Similar results of a live sperm were obtained by Davtyan et al. (2006) who indicated that the number of spermatozoa was also increased significantly by the use of selenium. Sefton and Edens (2004), found that the sperm quality index was greater in semen samples collected from males fed Sel-Plex ${ }^{\mathrm{TM}}$. Also, normal sperm number was significantly increased while abnormal number was significantly decreased compared with group fed sodium selenite. Edens (2002) found that the inclusion of selenium in poultry diets enhances sperm number, and using an organic source (Sel-Plex ${ }^{\mathrm{TM}}$ ) reduces production of defective sperm, thereby having a positive effect on the fertilizing potential of the male. Our results in sperm concentration are supported by Renema (2006) who found that feeding broiler breeder males (between $45-65$ weeks of age) $0.2 \mathrm{mg} / \mathrm{kg} \mathrm{Sel-Plex}{ }^{\mathrm{TM}}$ increased semen concentration. Also, Spring (2006) indicated significant improvements in spermatozoa concentration and activity, when fed diets were supplemented with Se yeast in comparison to selenite. Significant improvements in semen physical properties and seminal malondialdehyde concentration were observed as affected by supplementing $\mathrm{Cr}$ from Cr-Met compared with those for control group (Table 6). The improvement in semen physical properties might be due to the action of antioxidants of chromium which reduced the oxidants damage and maintained the integrity of cell membrane. This result agrees with previous studies which showed that chromium is an antioxidant and influences lipid peroxidation by fighting free radical damage in the body (Gallaher et al., 1993). The reduced in seminal malondialdehyde might also be due to the ability of $\mathrm{Cr}$ antioxidants in the supplementations to resist the lipid peroxidation damage in the spermatozoa. Moreover, there is a significant correlation between increase in MDA level and decrease in fertility has been shown by Douard et al. (2003). The depression in malondialdehyde level is an indicator for the degree of sperm membranes integrity and their fertilizing ability (Long and Kramer, 2003).

Vitamin $\mathrm{C}$ has been demonstrated to be a powerful antioxidant that acts through a two-way mechanism, that is, through its conversion to L-dehydroascorbic acid, a particularly inert radical, this reaction is reversible and the interconversion of these molecules forms a redox system, and the basic physiology of their actions, as both show vitamin C activity. The other route, is the formation of an ascorbate radical that destroys free radicals generated by oxygen, which includes hydroxyl $(\mathrm{OH} \cdot)$, monooxygen $(\mathrm{O} \cdot)$ and the superoxides $(\mathrm{O} 2 \cdot)$ and also in the transfer of radical equivalents from lipid phases to aqueous compartment. In realizing this function, the vitamin enters into a synergistic action with other protective antioxidant enzymes, such as: catalase (CAT), superoxide dismutase (SOD) and glutathione peroxidase (GSHPx). Puthpongsiriporn et al. (2001) confirmed in vitro that the addition of vitamin C reduced the rate of proteolytic induction by hydrogen peroxide $\left(\mathrm{H}_{2} \mathrm{O}_{2}\right)$ and the destruction of SOD.

\section{Fertility and hatchability \%:}

Hatchability percentage and hatch chick weight of Dokki-4 layers as affected by dietary supplementation of either $\mathrm{Cr}$, vitamin $\mathrm{C}$, Se or their mixtures during hot summer condition are presented in Table (7). Supplementation of $\mathrm{Cr}$, vitamin $\mathrm{C}$ or Se either individually or at any combination significantly $(\mathrm{P}<0.05)$ increased hatchability percentage comparable to control birds.

Ciftci et al. (2005) reported that, exposure of Japanese quails and laying hens to high ambient temperatures caused reduction in reproductive activities and egg quality respectively. The reduction in reproductive performance associated with heat stress is a well-known phenomenon in domestic birds (Daghir, 2009). This is probably due to the direct debilitating effect of high ambient temperature on ovarian function in the birds (Rozenboim et al., 2007). A possible mechanism for the reduction of ovarian function might be the reduction in blood flow to the ovary; a differential ovarian blood flow pattern was found in hens exposed to high ambient temperatures (Mashaly et al., 2004). 
The improvement in hatchability percentages could be attributed to the improvement in egg shell quality (Abdel-Mageed and Hassan 2012), since the poor hatchability in hot climate may be partially due to thin shell eggs (Daghir 1995). These results agree with those reported by Anderson (1994) who reported that $\mathrm{Cr}$ is thought to be essential for activating certain enzymes and for stabilizing proteins and nucleic acids which lead to increase fertility and hatchability percentages. Likewise Hanafy (2011) found that fertility and hatchability percentages significantly $(\mathrm{p} \leq 0.05)$ increased with the increase of dietary organic Cr levels from 250 to 1500 ppb Cr. Similarly, Contreras and Barajas (2001) reported that supplementing $400 \mu \mathrm{g} \mathrm{Cr} / \mathrm{kg}$ diet from Cr-Met improved hatchability in Japanese quail during winter season compared with the control (74 vs $64.8 \%$ respectively). Also, Contreras et al. (2000) showed that $200 \mathrm{ppb}$ Cr-Met supplementation improves hatchability in Japanese quail under weather controlled conditions in dry tropic areas $\left(25^{\circ} \mathrm{C}\right)$. However, Abd El-Samee et al. (2012) reported that supplementing diets with 600 or $1200 \mu \mathrm{g} \mathrm{Cr}$-yeast/ kg diet had no effects on fertility and hatchability percentages in quail.

Vitamin C is known to decrease the use of corticosteroids released during stress (Sahin et al., 2003), thus playing an important role in response to stress. Single or combined dietary supplementation with vitamin $\mathrm{C}, \mathrm{Cr}$ and Se of laying hens exposed to heat stress in this study has significantly improved the fertility and hatchability parameters. Dietary additions of Se alone or with other feed additives appeared to be more beneficial for laying hens during heat stress, probably due to its concurrent function as a fertility factor (Kevin, 1982). In addition, Hassan (1990) reported that the effects of Se deficiency (at 0.03 $\mathrm{mg} / \mathrm{kg}$ ) in the diet of White Leghorn caused a significant reduction in hatchability. Oishi et al. (1988) reported that low- Se diet decreased LH hormone. Agate et al. (2000) showed that Se as Sel-Plex supplementation in laying hen diets improved the environment of the sperm storage tubules in the hen's oviduct, allowing sperm to live longer, increasing the length of time sperm can be stored and increasing the average number of sperm holes in the yolk layer. Also, Hanafy et al. (2009) reported that Se as SelPlex supplementation increased the hatchability of fertile eggs and number of hatched for laying hen. Osman et al. (2010) showed that Se supplementation increased hatchability, this may be due to improved anti-oxidant status. In this respect, Davtyan et al. (2006) and Petrosyan et al. (2006), reported that a primary effect is on the breeder performance through a higher number of viable chicks produced and lower mortality of embryos during incubation, while the second effect of Se is on the males by maintaining sperm quality long time when stored in sperm storage tubules after mating and quantity is of major interest.

The protective effects of $\mathrm{Cr}$, Se or vitamin $\mathrm{C}$ are apparent especially during the highly oxidative state of late incubation and the first few days after hatch, concerning to Se, this result agrees with ( Surai, 2000). Hatched chicks produced from hens fed dietary supplementation of either $\mathrm{Cr}$, vitamin $\mathrm{C}$, Se or their mixtures during hot summer condition were significantly heavier than those of the group fed the basal diet (Table 7). Similar results were reported by Sefton and Edens (2004) and Pappas et al. (2006) who found that the chick weights from parents fed diets high in Se were heavier at hatch than those hatched from parents fed diets low in Se.

In this experiment, the single or combined dietary supplementation with chromium, vitamins $\mathrm{C}$ and selenium in laying chickens exposed to summer tropical hot-humid climate, have significantly improved reproductive performance, egg quality profiles of: egg weight, egg yolk weight, egg albumen weight and eggshell weight. However, it is interesting to note that supplementation of these antioxidants appeared to be more beneficial for laying hens during heat stress. Probably, due to their synergistic actions in quenching free radicals generated during heat stress (Ciftci et al., 2005). The synergic effects between these additives are particularly efficient for reducing production of reactive oxygen species in both aqueous and lipid phase of the cell membrane, and because radical reactions are exergonic, they contribute to the failure of thermoregulatory process in hyperthermia observed during heat stress (Mujahid et al., 2005).

\section{CONCLUSIONS}

By increasing reproductive performance and egg quality profiles, the administration of both antioxidants demonstrated their positive effects at ameliorating the adverse conditions of the hot-humid summer period under which the birds were reared. It is therefore recommended that both antioxidants be incorporated into laying hen's daily routine feeds as a nutritional strategy towards sustaining reproductive performance and egg quality productions, particularly during the hot summer periods.

\section{REFERENCES}


Abd El-Samee, L.D.; I. El-Wardany; N.G. Ali and O.M. Abo-El-Azab (2012). Egg quality, Fertility and hatchability of laying quail fed diets supplemented with organic chromium yeast or mannan oligosaccharides, Int. J. Poult. Sci., 11: 221-224.

Abdel-Mageed, M.A.A. and Hanan A. Hassan (2012). Effect of chromium-methionine chelate on performance and some plasma constituents of laying Japanese quail during summer months. Egypt. Poult. Sci., (2(IV): 883-894.

Allen, C. J. and L. R.Champion (1955). Competitive fertilization in the fowl. Poult. Sci., 34:1332-1342.

Ali, M.N.; M.S. Hassan and F.A. Abd El-Ghany (2007). Effect of strain, type of nature antioxidant and sulphate ion on productive, physiological and hatching performance of native laying hens. International J. Poultry Sci., 6 (8):539-554.

Anderson, R.A. (1994). Stress effects on chromium nutrition of humans and farm animals. In: Biotecnology in the feed Industry (Lyons, T. P\& Jacques, K. A., eds). PP. 267-274. University press, Nottingham, UK.

Agate, D.D.; E.E. Dea and M.E. Rustad (2000). Effects of dietary selenium on laying hen fertility as assessed by the periviteline sperm hole assay. Proceedings of the Poultry Research and Production Symposium. Alberta Poultry Research Centre. pp. 1-4.

AOAC (2005). Association of Official Analytical Chemists. Official methods of analysis. $18^{\text {th }}$ Ed. Published by the AOAC.,Washington, D. C. USA.

Blom, E. (1950). A 1-min live-dead sperm stain by means of eosin-nigrosin. J. Fertil, Steril., 1:176-177.

Bollengier-Lee, S.; M.A. Mitchell; D.B. Utomo; P.E.V. Williams and C.C. Whitehead (1998). Influence of high dietary vitamin $\mathrm{E}$ supplementation on eg production and plasma characteristics in hens subjected to heat stress. Br. Poult. Sci., 39:106- 112.

Chee, K.M.; M.K. Chung; J.H. Choi and Y.K. Chung (2005). Effects of dietary vitamins C and E on egg shell quality of broiler breeder hens exposed to heat stress. Asian-Aust. J. Anim. Sci., 18:545-551.

Cheng, T.K.; C.N. Coon and M.L. Hamre (1990). Effect of environmental stress on the ascorbic acid requirement of laying hens. Poultry Sci., 69:774-780.

Ciftci, M.; O. Nihat Ertas and T. Guler (2005). Effects of vitamin E and vitamin C dietary supplementation on egg production and egg quality of laying hens exposed to a chronic heat stress. Rev. Med. Vet., 156: 107-111.

Contreras, G. and R. Barajas (2001). Effect of chromium-methionine level in diet on hatchability of Japanese quail in dry tropic weather: II. Response under temperature-controlled in winter season. Poult. Sci., 80:323 (abstract).

Daghir, N.J. (2009). Nutritional strategies to reduce heat stress in broilers and broiler breeders. Loh. Inform., 44:6-15.

Davtyan, D.; T. Papazyan and L. Nollet (2006). Dose response of Se added as sodiumselenite or Sel-Plex on male sperm quality and breeder productivity. XII European Poultry Conference, Verona, Italy, 1014 September.

Desoky, A.A. (2008). Effect of dietary vitamin c and e supplementation on performance of laying hens under high environmental temperature. Egypt. Poult. Sci., 28:489-500.

Douard, W.; D. Hermier; M. Magistrini and E. Blesbois (2003). Reproductive period affects lipid composition and quality of fresh and stored spermatozoa in turkeys. Theriogenology, 59:753-764.

Duncan, D. B. (1955). Multiple range and multiple F-test. Biometrics, 11: 1-42.

El-Boushy, A.R.; P.C.M. Simons and G. Wiertz (1998). Structure and ultrastructure of the hen's egg shell as influenced by environmental temperature, humidity and vitamin C additions.Poult. Sci., 47:456467.

El-Gendi, G.M.; M.M. Iraq and A.A. Abd El- Rahman (1999). Effect of vitamin C supplementation on some productive and physiological parameters in laying hens. Egyptian J. Nutr. and Feeds, 2 (Special Issue): 649-664.

Eisen, E. J., B. B.Bohren and H. E. Mckean. (1962). The haugh unit as a measure of egg albumen quality. Poult. Sci., 41:1461-1468.

Edens, F.W. (2002). Practical applications for selenomethionine: broiler breeder reproduction In: Biotechnology in the Feed Industry. Proceeding of Alltech,s the $18^{\text {th }}$ Annual Symposium Edited by Lyons, T. P. and K. A. Jacques, Nottingham University Press, Nottingham, UK. 29-42.

Eseceli, H.; N. Degirmencioglu and M. Bilgic (2010). The effect of inclusion of chromium yeast ( Cofactor II, Alltech Inc. ) and folic acid to the rations of laying hens on performance, egg quality, egg yolk cholesterol, folic acid and chromium levels. J. Anim. Vet. Advan., 9:384-391.

Essa, N.M. and A.H. Madian (2009). The influence of casein supplementation with or without iodine on productive performance and egg quality of Fayomi hens. Egypt. Poult. Sci., 29 (1): 373 - 384. 
Flohe, L. and R. Zimmermann (1970). The role of GSHperoxidase in protecting the membrane of rate liver mitochondria. Biochim. Bio. Acta, 223:210-213.

Folch, J.; M. Lees; G.H. Sloane Stanley (1957). A simple method for the isolation and purification of total lipids from animal tissues. J. Biol. Chem., 226:497-509.

Funk, E.M.; G. Froning; G. Grottes; R. Forward and J. Kinder (1958). Quality of eggs laid caged layers. World Poult. Sc. J., 14:207.

Gallaher, D.D.; A.S. Csallany; D.W. Shoeman and J.M. Olson (1993). Diabetes increases excretion of urinary malondehyde conjugates in rats. Lipids, 28:663-666.

Hassan, S. (1990). Influence of dietary sodium selenite and barley selenium on the performance of laying hens and their subsequent progeny. Acta Agriculture Scandinavica, 40(3):267-278.

Hanafy, M.M.; A.M.H. El-Sheikh and E.A. Abdalla (2009). The effect of organic selenium supplementation on productive and physiological performance in a local strain of chicken. 1- The effect of organic selenium (sel-plex TM) on productive, reproductive and physiological traits of bandarah local strain. Egypt. Poult. Sci., 29: 1061-1084.

Hanafy, M. Maysa (2011). Influence of adding organic chromium in diet on productive traits, serum constituents and immune status of bandarh laying hens and semen physical properties for cocks in winter season. Egypt. Poult. Sci., 31:203-216.

Haugh, R.R. (1937). The Haugh unit for measuring egg quality. US Egg Poultry Magazine, 43:552-555.

Hood, J.E. (1999). An attempt at alleviating heat stress infertility in male broiler breeder chickens with dietary ascorbic acid. MS Thesis. Mississippi State University, Mississippi State, MS.

Hossain, S.M. (1998). Organic chromium in poultry: Metabolic responses, effects on broiler carcass compasition, nutrient composition of eggs. In: Layons, T. P. and K. A. Jacques (Eds.). Biotechnology in the Feed Industry. Nottingham University Press, Nottingham, UK 203-216.

Kadim, I.T.; B.H.A. Al-Qamshui; O. Mahgoub; W. Al- Marzooqi and E.H. Johnson (2008). Effect of seasonal temperatures and ascorbic acid supplementation on performance of broiler chickens maintained in closed and open-sided houses. Int. J. Poult. Sci., 7:655-660.

Kalamah, M.A.; M.M. El-Nadi; L.M. Goher and M.M. Soliman (2000). Some factors affecting fertility and hatchability using artificial insemination in Norfa chickens. $3^{\text {rd }}$ All Africa Conference on Animal Agric. and $11^{\text {th }}$ Conference of the Egyptian Society of Animal Production, Alex. Egypt, 6-9 November, 597-605.

Kevin, C. (1982): Vitamin E in poultry production. 1st Iberian Symposium of Aviculture. In: ROCHE Information Service, Animal Nutrition Department, Lisbon, Portugal, pp. 4-14.

Kirunda, D.F.K. and S.R. McKee (2000). Relating quality characteristics of aged eggs and fresh eggs to vitelline membrane strength as determined by a lexlure analyzer. Poultry Sci., 79:1189-1193.

Kutlu, H.R. and J.M. Forbes (1993). Changes in growth and blood parameters in heat-stressed broiler chicks in response to dietary ascorbic acid. Livest. Prod. Sci., 36:335-350.

Lien, T.F.; Y.M. Hornig and K.H. Yang (1999). Performance, serum characteristics, carcass traits and lipid metabolism of broilers as affected by supplement of chromium picolinate. Br. Poult. Sci., 40:357-363.

Long, J.A. and M. Kramer (2003). Effect of vitamin E on lipid peroxidation and fertility after artificial insemination with liquid- stored turkey semen. Poult. Sci. 82: 1802-1807.

Mahmoud, K.Z.; M.M. Beck; S.E. Scheideler; M.F. Forman; K.P. Anderson and S.D. Kachman (1996). Acute high environmental temperature and calcium- estrogen relationship inthe hen. Poult. Sci., 75:1555-1562.

Mashaly, M.M.; G.L. Hendricks; M.A. Kalama; A.E. Gehad; A.O. Abbas and P.H. Patterson (2004). Effect of heat stress on production parameters and immune responses of commercial laying hens. Poult. Sci., 83:889-894.

Marai, I.F.M.; M.S. Ayyat and U.M. Abd El-Monem (2001). Growth performance and reproductive traits at the first parity of New Zealand white female rabbits as affected by hot climate and its alleviation under Egyptian conditions. Trop. Anim. Health Prod., 33:451-462.

Marai, I.F.M.; A.A. Habbeb and A.E. Gad (2002). Rabbits productive, reproductive and physiological performance traits as affected by hot climate: a review. Livest. Prod. Sci., 78:71-90.

Marshall, A.C.; A.R. Sams and M.E. Van Elswyk (1994). Oxidative stability and sensory quality of stored eggs from hens fed 1.5\% menhaden oil. J. Food Sci., 59:561-563.

McDowell, L.R. (1989). Vitamins in animal nutrition: vitamin C, folacin. In: Comparative Aspects to Human Nutrition (McDowell, L. R., ed.), 298-322.

Melrose, D.R. and J.A. Lating (1970). The characteristics of normal semen. Chap. 4-Fertility and infertility in the Domestic animals. Ed. By J. A. Laing Bailliere Tindall and Gasssell, London.

Metwally, M.A. (2005). Efficacy of different dietary levels of antioxidants vitamin C, E and their combination on the performance of heat-stressed laying hens. Egypt. Poult. Sci., 25:613-636. 
Monsi, A. and D.O. Onitchi (1991). Effects of ascorbic acid (vitamin C) supplementation on ejaculated semen characteristics of broiler breeder chickens under hot and humid tropical conditions. Anim. Feed Sci. Tech., 34:141.

Mowat, D.N. (1994). Organic chromium. Anew nutrient for stressed animals. In: Biotechnology in the feed Industry (Lyons. T. P \& Jacques, K. A.,pp. 275-282. University press, Nottingham. UK.

Mujahid, A.; Y. Yoshiki; Y. Akiba and M. Toyomizu (2005). Superoxide radical production in chicken skeletal muscle induced by acute heat stress. Poult. Sci., 84:307-314.

National Research Council (1994). Nutrient requirements of chickens. In: Nutrient requirements of poultry (9th Ed.) National Academy of Science Washington D. C., pp. 19-26.

Noll, S.L. (1997). Vitamin C for turkey breeders. Proc. of the Arkansas Nutrition Conf., Arkansas Poult. Federation, Little Rock, Arkansas.

Oishi, T.; K. Yoshida; S. Morigchi and S. Inuzuka (1988). Effect of low-selenium diet on plasma lutenzing hormone, follicle stimulating hormone and estradiol in pullets and laying hens. Japanese Poultry Science. 25(5):337-342.

Osman, A.M.R.; H.M. Abdel-Wahed and M.S. Ragab (2010).Effects of supplementing laying hens diets with organic selenium on egg production, egg quality, fertility and hatchability. Egypt. Poult. Sci., 30:893-915.

Pappas, A.C.; T. Acamovic; N.H.C.Sparks; P.F. Surai and R.M. McDevitt (2005). Effects of supplementing broiler breeder diets with organic selenium and polyunsaturated fatty acids on egg quality during storage. Poult. Sci., 84:865-874.

Pappas, A.C.; T. Acamovic; N.H.C. Sparks; P.F. Surai and R.M. McDevitt (2006). Maternal organoselenium compounds and polyunsaturated fatty acids affect progeny performance and levels of selenium and docosahexaenoic acid in the chick tissues. Poult. Sci. 85: 1610-1620.

Pavlik, A.; L.M. Martina and P. Jelinek (2009). Blood plasma mineral profile and qualitative indicators of the eggshell in laying hens in different housing systems. Acta Vet Brno., 78:419-429.

Petrosyan, A.; T. Papazyan and L. Nollet (2006). Administration of Se as Sel-Plex on top of Sodiumselenite still improves fertility of hatchability of a broiler breeder flock. XII European Poultry Conference, Verona, Italy, 10-14 September.

Piva, A.; E. Meola; P.P. Gatta; G.C. Biagl; A.L. Mordenti; J.B. Luchansky and S. Silva (2003). The effect of dietary supplementation with trivalent chromium on production performance of laying hens and the chromium content in the yolk. Anim. Feed Sci. Technol., 106:149-163.

Puthpongsiriporn, U.; S.E. Scheideler; J.L. Sell; M.M. Beck (2001). Effects of vitamin E and C supplementation on performance, in vitro lymphocyte proliferation and antioxidant status of laying hens during heat stress. Poult. Sci., 80:1190-1200.

Radwan, Nadia L.; R.A. Hassan; E.M. Qota and H.M. Fayek (2008). Effect of natural antioxidant on oxidative stability of eggs and productive and reproductive performance of laying hens. International Journal of Poultry Science, 7(2):134-150.

Romanoff, A.L. and A.J. Romanoff (1949). In “The Avian egg” John Wiley and Sons; Inc., New York, U.S.A.

Renema, R.A. (2006). Creating the ideal hatching egg: Quality, efficiency and fertility.Nutritional biotechnology in the feed and food industries: Proceedings of Alltech,s 22nd Annual Symposium, Lexington, Kentucky, USA, 23-26.

Richard, M.J.; B. Portal; J. Meo; C. Coudray; A. Hadjian and A. Favier (1992). Malondialdehyde kit evaluated for determining plasma and lipoprotein fractions that react with thiobarbituric acid. Clin. Chem., 38:704-709.

Rozenboim, I.; E. Tako; O. GAL-Garber; J.A. Proudman and Z. Uni (2007): The effect of heat stress on ovarian function of laying hens. Poult. Sci., 86:1760-1765.

SAS (2003). SAS User's Guide: Statistics. Version 8.2, SAS Institute Inc., Cary, NC.

Sahin, N. and K. Sahin (2001). Optimal dietary concentrations of vitamin C and chromium picolinate for alleviating the effect of low ambient temperature $\left(6.2^{\circ} \mathrm{C}\right)$ on egg production, some egg characteristics, and nutrient digestibility in laying hens. Vet. Med.-Czech, 46:229-236.

Sahin, K.; O. Küçük; N. Sahin and O. Ozbey (2001). Effects of dietary chromium picolinate supplementation on egg production, egg quality and serum concentrations of insulin, corticosterone, and some metabolites of Japanese quails. Nutr. Res., 21:1315-1321.

Sahin, K.; O. Ozbey; M. Onderci; G. Cikim and M.H. Aysondu (2002). Chromium supplementation can alleviate negative effects of heat stress on egg production, egg quality and some serum metabolites of laying Japanese quail. J. Nutr., 132:1265-1268.

Sahin, K.; M. Onderci; N. Sahin; M.F. Gursu and O. Kucuk (2003). Dietary vitamin C and folic acid supplementation ameliorates the detrimental effects of heat stress in Japanese quail. J. Nutr., 133:1882-1888. 
Samli, H.E.; A. Agma and N. Senkoylul (2005). Effects of storage time and temperature on egg quality in old laying hens. J. Appl. Poult. Res., 14:548-553.

Sara, A.; M. Bennea; A. Odagiu and L. Panta (2008).Effects of the organic selenium (Sel-Plex) administered in laying hens' feed in second laying phase on production performance and eggs quality. Bulletin UASVM Animal Science andBiotechnologies, 65:1-2.

Schwarz, K. and C. M .Foltz (1957). Selenium as an integral part of factor 3 against dietary necrotic liver degeneration. J. Am. Chem. Soc., 79: 3292-3293.

Seaborn C.D; N. Chang; B. Adeleye; F. Owens and B.J. Stoecker (1994). Chromium and chronic ascorbic acid depletion effects on tissue ascorbate, manganese, and 14C retention from 14C-ascorbic in guinea pigs, Biol. Trace Elem Res; 41:479-285.

Sefton, A.E. and F.W. Edene (2004). Sel-Plex improves broiler breeder performance. Book of Abstracts XXII World,s Poultry Congress, 8-13 June , 2004, Istanbul , Turkey, p.257.

Simon, S. (2004). Alltech symposium highlights.World Poult., 20:12-13.

Spring, P. (2006).Poultry health through nutrition. World Poult. 22:26-29.

Surai, P.F. (2000). Effect of selenium and vitamin E content of the maternal diet on the antioxidant system of the yolk and the developing chick. Br. Poult. Sci., 41:235-243.

Surai, P.F. (2002). Selenium in poultry nutrition. 1. Antioxidant properties, deficiency and toxicity. World's Poult. Sci. I., 58:333-347.

Surai, P.F.; E. Blesbois; I. Grasseau; T. Chalah; J.P. Brillard; G.J. Wishart; S. Cerolini and N.H.C. Sparks (1998). Fatty acid composition, glutathione peroxidase and superoxide dismutase activity and total antioxidants activity of avian semen. Comp. Biochem. Physiol. B. Biochem. Mol. Biol., 120:527-533.

Taylor, T.G. and C.G. Drake (1984). Calcium metabolism and its reglation in: Freeman, B.M. (Ed.) Physiology and Biochemistry of the Domestic Fowl. 5:125-170 (London, Academic Press).

Tojo, H. and T.M. Huston (1980). Effects of environmental temperature on the concentration of serum ostradiol, progesterone and calcium in maturing female domestic fowl. Poult. Sci., 59:2797-2802.

Utterback, P.L.; C.M. Parsons; I. Yoon and J. Butler (2005). Effect of supplementing selenium yeast in diets of laying hens on egg selenium content. Poult. Sci., 1900-1901.

Uyanik, F.; S. Kaya; A.H. Kolsuz; M. Eren and N. Sahin (2002). The effects of chromium supplementation on egg production, egg quality and some serum parameters in laying hens. Turk. J. Vet. Anim. Sci., 26:379-387.

Wakebe, M. (1998). Feed for chicken and for hen. Japanese Patent Office, Patent number. JP 10023864 A2. Jan. 27.

Wang, J.J. and T.M. Pan (2003). Effect of red mold rice supplements on serum and egg yolk cholesterol levels of laying hens. J. Agric. Food Chem., 51:4824-4829.

Yardibi, H. and G. Türkay, (2008). The Effects of Vitamin E on the Antioxidant System, Egg Production, and Egg Quality in Heat Stressed Laying Hens. Turk. J. Vet. Anim. Sci., 32:319 -325.

Yaroshenko, F.A.; J.E. Dvorska; P.F. Surai, and N.H.C. Sparks (2003). Selenium/ Vitamin E enriched egg :Nutritional quality and stability duringstorage/ Poster Presented at Alltechs $19^{\text {th }}$ Annual Symposium on Nutritional Biotechnology in the Feed and Food Industries Lexington KY 12- 14. ROM-CD.

Yeşilbağ, D. and M. Eren (2009). Effects of dietary organic and inorganic chromium supplementation on performance, egg shell quality and serum parameters in Pharaoh Quails. J. Biol. Environ. Sci., 3:3135.

Yildiz, A.O.; S.S. Parlat and O. Yazgan (2004). The effects of organic chromium supplementation on production traits and some serum parameters of laying quail. Revue. Med. Vet., 155:642-646. 
Table (1). Composition of the basal experimental diet.

\begin{tabular}{|c|c|}
\hline Ingredients & $\%$ \\
\hline Yellow corn & 66.00 \\
\hline Soybean meal (44\%) & 24.00 \\
\hline Limestone & 7.59 \\
\hline Di-calcium phosphate & 1.71 \\
\hline Sodium chloride & 0.30 \\
\hline Vit.\& Min. Mixture* & 0.30 \\
\hline DL.Methionine & 0.10 \\
\hline Total & 100 \\
\hline \multicolumn{2}{|l|}{ Calculated analysis** } \\
\hline Metabolizable energy (kcal/ kg) & 2750 \\
\hline Crude Protein, $\%$ & 16.43 \\
\hline Crude fiber, $\%$ & 3.20 \\
\hline Ether extract, \% & 2.70 \\
\hline Calcium, \% & 3.33 \\
\hline Available phosphate, $\%$ & 0.45 \\
\hline Total phosphorus, $\%$ & 0.66 \\
\hline Lysine, \% & 0.86 \\
\hline Methionine, \% & 0.39 \\
\hline \multicolumn{2}{|l|}{ Determined analysis } \\
\hline Crude Protein, $\%$ & 16.45 \\
\hline Crude fiber, $\%$ & 3.18 \\
\hline Ether extract, $\%$ & 2.68 \\
\hline Calcium, $\%$ & 3.50 \\
\hline Total phosphorus, $\%$ & 0.70 \\
\hline
\end{tabular}

Table (2). Temperature $\left({ }^{\circ} \mathrm{C}\right)$ and relative humidity \% during the experimental period from June to August, 2014*.

\begin{tabular}{ccccccc}
\hline \multirow{2}{*}{ Items } & \multicolumn{2}{c}{ AT $\left({ }^{\circ} \mathrm{C}\right)$} & \multicolumn{2}{c}{$\mathrm{RH}(\%)$} & \multicolumn{2}{c}{ THI } \\
\cline { 2 - 6 } & Minimum & Maximum & Minimum & Maximum & Minimum & Maximum \\
\hline June & 22.6 & 32.8 & 26.4 & 39.4 & 21.0 & 28.5 \\
July & 22.2 & 37.7 & 25.1 & 41.1 & 10.8 & 29.9 \\
August & 23.9 & 36.2 & 31.1 & 47.1 & 22.3 & 31.6 \\
\pm SE & 0.91 & 0.97 & 2.19 & 1.87 & 0.76 & 0.73 \\
\hline
\end{tabular}

* Central Laboratory for Agricultural Climate. 
Table (3). The effects of supplemental $\mathrm{Cr}$, Se or vit. C alone or in combination on egg quality of laying hens reared during summer conditions.

\begin{tabular}{|c|c|c|c|c|c|c|c|c|c|c|}
\hline \multirow[b]{2}{*}{ Treatments } & \multicolumn{10}{|c|}{ Egg quality } \\
\hline & $\begin{array}{c}\text { Egg } \\
\text { Weight } \\
(\mathrm{g})\end{array}$ & $\begin{array}{l}\text { Yolk } \\
\text { wt. \% }\end{array}$ & $\begin{array}{c}\text { Albumen } \\
\text { wt. } \%\end{array}$ & $\begin{array}{l}\text { Shell } \\
\text { wt. \% }\end{array}$ & $\begin{array}{c}\text { Egg } \\
\text { Shape } \\
\text { index } \\
\end{array}$ & $\begin{array}{l}\text { Yolk } \\
\text { index }\end{array}$ & $\begin{array}{c}\text { Shell } \\
\text { thickness } \\
(\mathrm{mm})\end{array}$ & $\begin{array}{c}\text { Haugh } \\
\text { unit }\end{array}$ & $\begin{array}{c}\text { Shell } \\
\text { calcium \% }\end{array}$ & $\begin{array}{c}\text { Shell } \\
\text { phosphorus } \\
(\mathrm{ppm})\end{array}$ \\
\hline Control group & 46.98 & $32.60^{\mathrm{a}}$ & $57.90^{c}$ & $9.38^{\mathrm{e}}$ & 74.70 & $44.15^{\mathrm{c}}$ & $0.321^{\mathrm{d}}$ & $80.12^{\mathrm{c}}$ & $32.5^{\mathrm{c}}$ & $1200^{\mathrm{e}}$ \\
\hline Cr-group & 47.44 & $29.86^{c}$ & $60.61^{\mathrm{a}}$ & $9.5^{\mathrm{d}}$ & 74.85 & $44.98^{\mathrm{ab}}$ & $0.356^{\mathrm{b}}$ & $82.15^{\mathrm{b}}$ & $33.8^{\mathrm{b}}$ & $1345^{\mathrm{d}}$ \\
\hline Vit. C-group & 46.98 & $29.03^{c}$ & $61.32^{\mathrm{a}}$ & $9.64^{\mathrm{cd}}$ & 74.95 & $44.87^{\mathrm{b}}$ & $0.348^{\mathrm{c}}$ & $83.05^{\mathrm{a}}$ & $33.7^{\mathrm{b}}$ & $1378.5^{\mathrm{d}}$ \\
\hline Se-group & 47.61 & $29.69^{c}$ & $60.32^{\mathrm{a}}$ & $9.97^{\mathrm{cd}}$ & 75.5 & $44.95^{\mathrm{b}}$ & $0.355^{\mathrm{b}}$ & $82.5^{\mathrm{ab}}$ & $34.1^{\mathrm{ab}}$ & $1542.5^{\mathrm{c}}$ \\
\hline $\mathrm{Cr}+$ vit.C-group & 47.49 & $31.03^{\mathrm{b}}$ & $59.57^{\mathrm{b}}$ & $9.89^{\mathrm{cd}}$ & 75.00 & $45.05^{\mathrm{ab}}$ & $0.354^{\mathrm{b}}$ & $83.75^{\mathrm{a}}$ & $34.7^{\mathrm{ab}}$ & $1560^{c}$ \\
\hline $\mathrm{Cr}+\mathrm{Se}$-group & 47.9 & $31.94^{\mathrm{b}}$ & $58.03^{\mathrm{bc}}$ & $10.02^{\mathrm{c}}$ & 74.85 & $45.62^{\mathrm{a}}$ & $0.360^{\mathrm{b}}$ & $82.95^{\mathrm{ab}}$ & $33.9^{b}$ & $1780^{\mathrm{a}}$ \\
\hline Se+vit.C-group & 47.88 & $31.28^{\mathrm{b}}$ & $56.82^{\mathrm{c}}$ & $11.88^{\mathrm{a}}$ & 75.11 & $45.7^{\mathrm{a}}$ & $0.358^{\mathrm{b}}$ & $82.68^{\mathrm{ab}}$ & $34.4^{\mathrm{b}}$ & $1698^{\mathrm{b}}$ \\
\hline $\mathrm{Cr}+\mathrm{Se}+\mathrm{Vit} . \mathrm{C}-$ group & 47.55 & $30.66^{\mathrm{ab}}$ & $58.88^{\mathrm{bc}}$ & $10.45^{\mathrm{b}}$ & 75.80 & $45.89^{a}$ & $0.373^{\mathrm{a}}$ & $83.25^{\mathrm{a}}$ & $35.2^{\mathrm{a}}$ & $1788.5^{\mathrm{a}}$ \\
\hline SEM & 0.231 & 0.069 & 0.082 & 0.059 & 0.193 & 0.257 & 0.003 & 0.193 & 0.069 & 0.525 \\
\hline $\mathrm{p}$-value & 0.10 & 0.004 & 0.006 & 0.0001 & 0.9 & 0.001 & 0.001 & 0.001 & 0.0001 & 0.0001 \\
\hline
\end{tabular}

a.b... Means on the same column differently superscripted are significantly different $(p \leq 0.05)$.

SEM = Standard error of means.

Table (4). The effects of supplemental $\mathrm{Cr}$, Se or vit. $\mathrm{C}$ alone or combination on chemical composition of fresh egg yolks at the end of the experimental period.

\begin{tabular}{|c|c|c|c|c|c|c|}
\hline \multirow[b]{2}{*}{ Treatments } & \multicolumn{6}{|c|}{ Egg yolk extract } \\
\hline & $\begin{array}{c}\text { Protein, } \\
\%\end{array}$ & $\begin{array}{c}\text { Total lipid, } \\
\%\end{array}$ & Cholesterol, mg/g & $\begin{array}{c}\text { H.D.L. } \\
\mathrm{mg} / \mathrm{g}\end{array}$ & $\begin{array}{l}\text { L.D.L. } \\
\mathrm{mg} / \mathrm{g}\end{array}$ & $\begin{array}{c}\text { Triglycerides } \\
\text { mg/g }\end{array}$ \\
\hline Control group & 19.2 & 27.2 & $23.60^{\mathrm{a}}$ & $10.09^{c}$ & $12.25^{\mathrm{a}}$ & $125^{\mathrm{a}}$ \\
\hline Cr-group & 19.1 & 27.9 & $21.70^{\mathrm{b}}$ & $10.25^{\mathrm{b}}$ & $10.78^{b}$ & $119^{\mathrm{b}}$ \\
\hline Vit. C-group & 19.3 & 28.1 & $21.10^{\mathrm{b}}$ & $10.33^{b}$ & $10.80^{\mathrm{b}}$ & $120^{\mathrm{b}}$ \\
\hline Se-group & 19.4 & 28.2 & $21.60^{\mathrm{b}}$ & $10.42^{b}$ & $10.24^{\mathrm{bc}}$ & $118^{\mathrm{bc}}$ \\
\hline $\mathrm{Cr}+$ vit.C-group & 18.9 & 28.3 & $21.17^{\mathrm{b}}$ & $10.85^{\mathrm{a}}$ & $10.22^{b c}$ & $117^{\mathrm{bc}}$ \\
\hline $\mathrm{Cr}+\mathrm{Se}$-group & 19.3 & 27.3 & $20.50^{c}$ & $10.79^{\mathrm{ab}}$ & $10.35^{\mathrm{bc}}$ & $115^{\mathrm{c}}$ \\
\hline Se+vit.C-group & 19.2 & 27.6 & $21.44^{\mathrm{b}}$ & $10.87^{\mathrm{a}}$ & $10.05^{\mathrm{bc}}$ & $115^{\mathrm{c}}$ \\
\hline $\mathrm{Cr}+\mathrm{Se}+\mathrm{Vit} . \mathrm{C}-$ group & 19.7 & 27.2 & $20.50^{c}$ & $10.93^{\mathrm{a}}$ & $9.55^{\mathrm{c}}$ & $112^{\mathrm{d}}$ \\
\hline SEM & 0.213 & 0.144 & 0.477 & 0.07 & 0.32 & 0.94 \\
\hline p-value & 0.47 & 0.39 & 0.002 & 0.0001 & 0.0001 & 0.0001 \\
\hline
\end{tabular}

$a . b \ldots=$ Means on the same column differently superscripted are significantly different $(p \leq 0.05)$.

SEM = Standard error of means. 
Table (5). The effects of supplemental $\mathrm{Cr}$, Se or vit. C alone or combination on egg content pH and egg yolk maloaldehyde during storage time.

\begin{tabular}{|c|c|c|c|c|c|c|c|c|}
\hline \multirow{3}{*}{ Treatments } & \multicolumn{4}{|c|}{ Storage time } & \multicolumn{4}{|c|}{ Storage time } \\
\hline & \multicolumn{4}{|c|}{ Egg content $\mathrm{pH}$} & \multicolumn{4}{|c|}{ Egg yolk maloaldehyde ( $\mathrm{mg} / \mathrm{kg}$ yolk) } \\
\hline & Zero time & 5 days & 10 days & 15 days & Zero time & 5 days & 10 days & 15 days \\
\hline Control group & $7.60 \mathrm{a}$ & $7.83 \mathrm{a}$ & $7.89 \mathrm{a}$ & $7.99 a$ & $0.532 \mathrm{a}$ & $0.568 \mathrm{a}$ & $0.642 \mathrm{a}$ & $0.708 \mathrm{a}$ \\
\hline Cr-group & $7.45 b$ & $7.51 \mathrm{~b}$ & $7.55 b$ & $7.64 b$ & $0.425 b$ & $0.468 \mathrm{c}$ & $0.531 \mathrm{bc}$ & $0.601 \mathrm{c}$ \\
\hline Vit. C-group & $7.44 b$ & $7.49 b$ & $7.53 \mathrm{~b}$ & $7.62 b$ & $0.420 \mathrm{~b}$ & $0.452 b c$ & $0.523 c$ & $0.621 b$ \\
\hline Se-group & $7.44 \mathrm{~b}$ & $7.50 \mathrm{~b}$ & $7.60 \mathrm{~b}$ & $7.62 b$ & $0.412 \mathrm{c}$ & $0.500 \mathrm{~b}$ & $0.550 \mathrm{~b}$ & $0.600 \mathrm{c}$ \\
\hline $\mathrm{Cr}+$ vit.C-group & $7.43 b$ & $7.52 b$ & $7.58 \mathrm{~b}$ & $7.63 b$ & $0.408 \mathrm{bc}$ & $0.489 b$ & $0.518 \mathrm{c}$ & $0.588 \mathrm{~d}$ \\
\hline $\mathrm{Cr}+\mathrm{Se}$-group & $7.40 \mathrm{~b}$ & $7.60 \mathrm{~b}$ & $7.61 b$ & $7.65 b$ & $0.412 \mathrm{c}$ & $0.492 b$ & $0.538 b$ & $0.589 \mathrm{~d}$ \\
\hline Se+vit.C-group & $7.43 b$ & $7.55 b$ & $7.62 b$ & $7.66 \mathrm{~b}$ & $0.408 b c$ & $0.485 b$ & $0.547 b$ & $0.585 \mathrm{~d}$ \\
\hline $\mathrm{Cr}+\mathrm{Se}+\mathrm{Vit} . \mathrm{C}$ - group & $7.42 \mathrm{~b}$ & $7.50 \mathrm{~b}$ & $7.53 b$ & $7.60 \mathrm{~b}$ & $0.401 b c$ & $0.478 b c$ & $0.521 \mathrm{c}$ & $0.580 \mathrm{~d}$ \\
\hline SEM & 0.011 & 0.029 & 0.031 & 0.030 & 0.001 & 0.005 & 0.010 & 0.009 \\
\hline p-value & 0.001 & 0.008 & 0.01 & 0.009 & 0.001 & 0.0089 & 0.0008 & 0.0001 \\
\hline
\end{tabular}

a.b... = Means on the same column differently superscripted are significantly different $(p \leq 0.05)$.

SEM $=$ Standard error of means.

Table (6). The effects of supplemental Cr, Se or vit. C alone or combination on semen quality of laying hens reared during summer conditions.

\begin{tabular}{|c|c|c|c|c|c|c|c|c|c|c|c|}
\hline Treatments & $\begin{array}{l}\text { Ejaculate } \\
\text { volume } \\
\quad(\mathrm{ml})\end{array}$ & $\begin{array}{c}\text { Sperm } \\
\text { concentration } \\
\left(\mathrm{x} 10^{6} \mathrm{ml}\right)\end{array}$ & $\begin{array}{l}\text { Total } \\
\text { sperm } \\
\text { output }\end{array}$ & $\begin{array}{l}\text { Sperm } \\
\text { motility } \\
(\%)\end{array}$ & $\begin{array}{c}\text { Total } \\
\text { motile } \\
\text { sperm } \\
\left(\mathrm{x} 10^{6} \mathrm{ml}\right)\end{array}$ & $\begin{array}{c}\text { Live } \\
\text { spermatozoa } \\
(\%)\end{array}$ & $\begin{array}{c}\text { Dead } \\
\text { spermatozoa } \\
(\%)\end{array}$ & $\begin{array}{c}\text { Sperm } \\
\text { abnormalities } \\
(\%)\end{array}$ & $\begin{array}{l}\text { Semen } \\
\text { quality } \\
\text { factor }\end{array}$ & $\mathrm{pH}$ & $\begin{array}{c}\mathrm{MDA} \\
(\mathrm{nmol} / \\
\mathrm{ml})\end{array}$ \\
\hline Control group & $0.22 c$ & 630d & $138.6 \mathrm{~d}$ & $60.00 \mathrm{c}$ & $83.16 \mathrm{e}$ & $62.54 \mathrm{~d}$ & $37.45 \mathrm{a}$ & $17.5 \mathrm{a}$ & $86.68 d$ & 7.90 & $1.78 \mathrm{a}$ \\
\hline Cr-group & $0.25 b$ & $686 c$ & $171.5 \mathrm{bc}$ & $67.5 b c$ & $115.76 \mathrm{~cd}$ & $73.20 b c$ & $30.45 b$ & $13.6 \mathrm{~b}$ & $125.53 c$ & 7.78 & $1.22 \mathrm{~b}$ \\
\hline Vit. C-group & $0.24 b c$ & $690 \mathrm{c}$ & $165.8 \mathrm{c}$ & $65.8 b c$ & $109.09 d$ & $73.00 \mathrm{bc}$ & $28.50 \mathrm{c}$ & $14.2 b$ & $120.88 \mathrm{c}$ & 7.75 & $1.32 \mathrm{~b}$ \\
\hline Se-group & $0.25 b$ & $685 c$ & $171.25 \mathrm{bc}$ & $66.8 b c$ & $114.39 \mathrm{~cd}$ & $72.98 \mathrm{c}$ & $29.00 \mathrm{bc}$ & $14.00 \mathrm{~b}$ & $124.97 \mathrm{c}$ & 7.78 & $1.18 \mathrm{c}$ \\
\hline $\mathrm{Cr}+$ vit.C-group & $0.25 b$ & $702 b$ & $175.5 b c$ & $72.5 b$ & $127.23 \mathrm{c}$ & $75.00 \mathrm{~b}$ & $28.00 \mathrm{c}$ & $12.6 \mathrm{c}$ & $131.62 b c$ & 7.72 & $1.08 \mathrm{c}$ \\
\hline $\mathrm{Cr}+\mathrm{Se}$-group & $0.26 \mathrm{ab}$ & $725 \mathrm{ab}$ & $188.5 b$ & $72.0 \mathrm{~b}$ & $135.72 b$ & $75.80 \mathrm{~b}$ & $26.1 \mathrm{~d}$ & $12.0 \mathrm{c}$ & $142.88 b$ & 7.68 & $1.10 \mathrm{c}$ \\
\hline Se+vit.C-group & $0.26 \mathrm{ab}$ & $730 \mathrm{ab}$ & $189.8 b$ & $73.0 \mathrm{~b}$ & $138.55 b$ & $75.67 b$ & $26.0 \mathrm{~d}$ & $12.0 \mathrm{c}$ & $143.62 b$ & 7.70 & $1.00 \mathrm{~d}$ \\
\hline $\mathrm{Cr}+\mathrm{Se}+\mathrm{Vit} . \mathrm{C}-$ group & $0.28 \mathrm{a}$ & $780 \mathrm{a}$ & $218.4 \mathrm{a}$ & $80.6 \mathrm{a}$ & $210.6 \mathrm{a}$ & $78.00 \mathrm{a}$ & $23.60 \mathrm{e}$ & $10.45 \mathrm{~d}$ & $170.35 \mathrm{a}$ & 7.67 & $0.95 \mathrm{~d}$ \\
\hline SEM & 0.08 & 106.22 & 42.28 & 7.29 & 42.88 & 3.65 & 1.93 & 2.35 & 26.25 & 0.11 & 0.075 \\
\hline p-vaue & 0.001 & 0.001 & 0.0001 & 0.002 & 0.0001 & 0.001 & 0.0001 & 0.0001 & 0.001 & 0.9 & 0.0001 \\
\hline
\end{tabular}

$a . b \ldots=$ Means on the same column differently superscripted are significantly different $(p \leq 0.05)$

SEM $=$ Standard error of means. 
Table (7). The effects of supplemental $\mathrm{Cr}$, Se or vit. $\mathrm{C}$ alone or combination on fertility, hatchability percentage and hatch body weight.

\begin{tabular}{ccccc}
\hline \multirow{2}{*}{ Treatments } & \multirow{2}{*}{ Fertility $\%$} & \multicolumn{2}{c}{ Hatchability $\%$} & \multirow{2}{*}{ Chick hatch weight $(\mathrm{g})$} \\
\cline { 3 - 4 } & & Total egg set & Fertile eggs & \\
Control group & 76.5 & $61.11^{\mathrm{c}}$ & $66.5^{\mathrm{c}}$ & 35.00 \\
Cr-group & 80.45 & $72.1^{\mathrm{ab}}$ & $80.25^{\mathrm{b}}$ & 35.15 \\
Vit. C-group & 80.9 & $72.8^{\mathrm{ab}}$ & $80.05^{\mathrm{b}}$ & 35.25 \\
Se-group & 81.0 & $71.8^{\mathrm{b}}$ & $80.5^{\mathrm{b}}$ & 35.12 \\
Cr+vit.C-group & 82.5 & $73.2^{\mathrm{a}}$ & $82.05^{\mathrm{ab}}$ & 35.85 \\
Cr+Se-group & 81.9 & $73.0^{\mathrm{a}}$ & $82.6^{\mathrm{ab}}$ & 35.67 \\
Se+vit.C-group & 82.6 & $72.9^{\mathrm{a}}$ & $82.9^{\mathrm{a}}$ & 35.48 \\
Cr+Se+Vit.C- group & 83.2 & $74.2^{\mathrm{a}}$ & $83.5^{\mathrm{a}}$ & 35.90 \\
SEM & 0.62 & 0.95 & 0.63 & 0.07 \\
p-value & 0.08 & 0.02 & 0.002 & 0.9 \\
\hline a.b... & Means on the same column differently superscripted are significantly different $(p \leq 0.05)$. \\
SEM $=$ Standard error of means. & \multicolumn{3}{|}{}
\end{tabular}

\title{
تأثير اضافة الكروميوم والسيلينيوم و فيتامين ج للعليقة على الكفاءة التناسلية و جودة البيض لسلالة دقى 4 المحلية تحت ظروف الصيف المصرية والئين.
}

\author{
خليل محمد عطية ، فؤاد احمد توفيق ، محمود صلاح ماضي و محمد حسني عصر. \\ معه بحوث الانتاج الحيوانسي - مركز البحوث الزراعية ـ دقي - مصر.
}

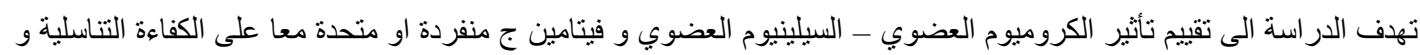

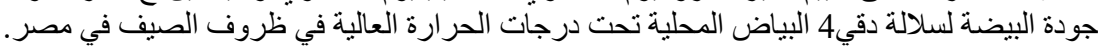

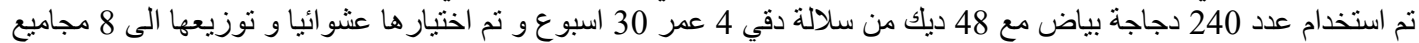

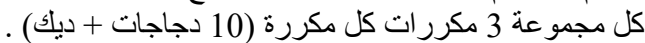

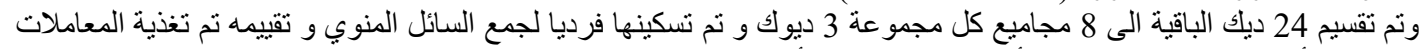

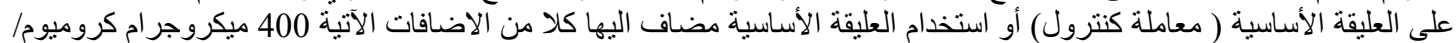

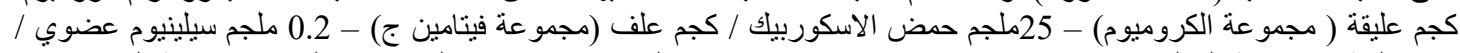

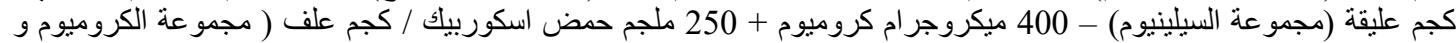

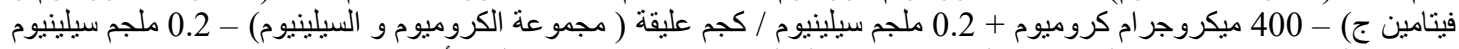

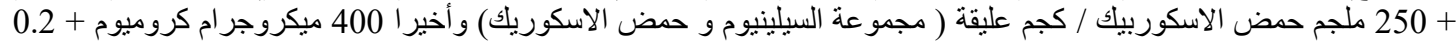

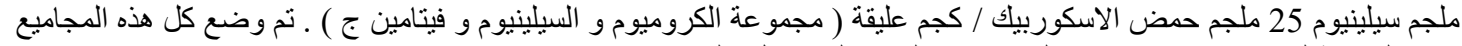

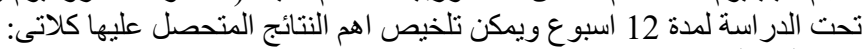

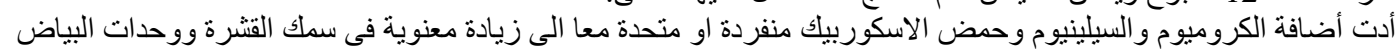

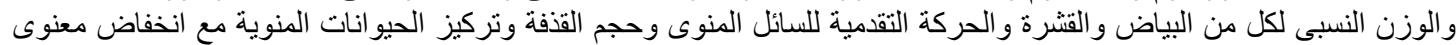

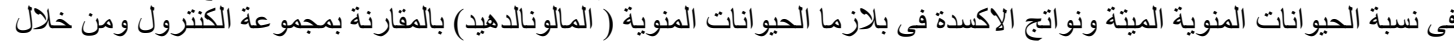

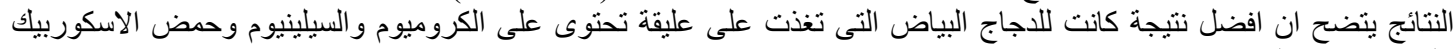
بالمقارنة بباقى المعاملات.

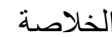

اضافة الكروميوم و السيلينيو وحمض الاسكوربيك أحدثت تحسن فى معظم الصفات التناسلية وجودة البيض لسلالة دقى4 تحت ظروف الصيف فى مصر. 